\section{Moderne krig og den psykiske helse}

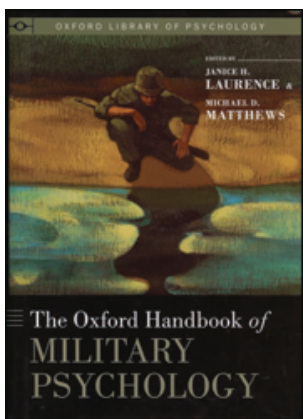

Janice H. Laurence,

Michael D. Matthews, red.

The Oxford handbook of military psychology

417 s, tab, ill. Oxford: Oxford University Press,

2012. Pris GBP 95

ISBN 978-0-19-539932-5

Denne utgivelsen er egnet som oppslagsverk. Den kan også brukes som lærebok, men er atskillig mer omfattende enn Kennedy \& Zillmers fra 2006.

Redaktørene og de fleste kapittelforfatterne er amerikanske, men engelske, israelske, svenske og norske militærpsykologer har også bidratt. Vår egen professor Jarle Eid skriver interessant om terrorens psykologi og illustrerer dermed en av de nye truslene som utfordrer dagens forsvar.

Vårt vernepliktsforsvar, innrettet for fedrelandskrig, er de siste 20 år blitt supplert med og til dels erstattet av et profesjonelt militært ekspedisjonskorps. Irak og Afghanistan er blitt velkjent bortebane for snart 10000 nordmenn, og alle disse har familier. Norge har over 100000 veteraner fra internasjonal tjeneste. Militære stormakter som USA har bare denne type krigserfaringer, og deres kunnskaper om militære helseutfordringer er derfor blitt viktigere for oss. De felles internasjonale styrkene deltar i dag i asymmetrisk krigføring mot en ofte usynlig fiende. De spesielle stresspåkjenningene som soldater erfarer og deres helsefølger blir godt dekket i denne utgivelsen. Den omhandler også tradisjonelle psykologiske temaer som testing, seleksjon, motivasjon, militærfamilien, gruppen og organisasjonen og militært lederskap. De nyere behandlingsmetoder for posttraumatisk stresslidelse og andre tjenesterelaterte psykiske lidelser er godt dekket.

Den mye medieomtalte økningen i antall selvmord blant amerikanske veteraner gis fyldig plass. Her kunne internasjonale sammenlikninger vært mer trukket inn.

Ingen nasjon har hittil greid å utvikle erstatningsordninger for krigsskader som alle de involverte parter finner rettferdige. Som kjent er det også blant helsefaglig personell en del uenighet om dette spørsmålet, og det er store variasjoner nasjonene imellom, noe en internasjonal håndbok kunne dekket bedre. De psykiske skadene er spesielt vanskelige å vurdere, særlig mange år i ettertid.

Det hadde også vært interessant om man hadde gått dypere inn i de oppsiktsvekkende forskjellene som er påvist i prevalens av psykiske skader og deres forløp mellom amerikanske og britiske styrker - som har deltatt i samme krig. At britene kommer best ut, er blitt forklart ved at deres nasjonale helsevesen ikke stiller krav til at plagene skal være tjenesterelatert for at veteranen skal få hjelp.

Av høyst aktuelle temaer som dekkes vil jeg fremheve diskusjonen om etiske dilemmaer. Eksemplet som drøftes er da amerikanske militærpsykologer skulle delta med rådgivning og helsetjenester i de skarpe avhørene av terrormistenkte etter 11. september. De ble da konfrontert med de etiske dilemmaer som leger nok tidligere fikk et avklart forhold til - det uakseptable ved å stille seg til disposisjon for metoder som må karakteriseres som tortur. Å holde fast ved profesjonsetikken som helsearbeider, eller som offiser underlagt Genèvekonvensjonene, blir da avgjørende. Diskusjonen om drøftingene i den amerikanske psykologforeningen er interessant lesning.

Hver krig synes å ha sin «signaturskade», som det såkalte Golfkrigssyndromet. I Afghanistan er det «minimal traumatic brain injury». Slike nye tilstander har ført til økt forskningsinnsats, som etter hvert er blitt mer tverrfaglig og prospektiv. I denne utgivelsen, som er utpreget forskningsbasert, drøftes de psykologiske aspekter ved disse tilstandene og ved medisinsk uforklarlige sykdommer.

The Oxford handbook of military psychology anbefales den som ønsker en aktuell, dokumentert og bred oversikt over hva militærpsykologien har av kunnskap og tilbud.

\section{Lars Weisæth}

Avdeling for psykisk helse og avhengighet

Institutt for klinisk medisin

Universitetet i Oslo

og

RVTS-Øst

Oslo universitetssykehus

\section{Ferske divertikler}

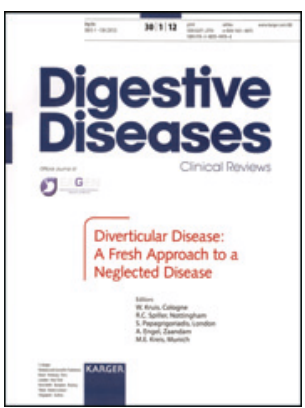

Wolfgang Kruis, Robin C. Spiller,

Savvas Papagrigoriadis et al., red.

Digestive diseases

Diverticular disease: a fresh approach

to a neglected disease. $138 \mathrm{~s}$, tab, ill.

Basel: Karger, 2012. Pris CHF 48

ISBN 978-3-8055-9978-8

Dette er et nummer av tidsskriftet Digestive Diseases fra mai 2012, som denne gang er viet divertikkelsykdom. Bakgrunnen var et ekspertsymposium, Falks symposium nr. 178, som ble avholdt 2.-3. november 2011. Bladet inneholder de fleste av innleggene som ble holdt der. Det er hovedsakelig rettet mot gastrokirurger og gastroenterologer, men også mot patologer og røntgenleger med interesse for feltet.

Boken, eller rettere sagt tidsskriftet, inneholder noen artikler om patogenese, to om forløpet av sykdommen, og så noen om diagnostikk. Deretter kommer det et betydelig antall artikler som går på behandling, både medisinsk og kirurgisk, førstegangs og ved residiv. Til slutt er det et par artikler om forskning.

Jeg finner få figurer, og de som finnes, er fargeløse og egentlig temmelig kjedelige. Tabellene likeså.

Innholdsmessig synes jeg man lever opp til ambisjonene om å gå gjennom den seneste litteraturen og si noe om de kliniske implikasjonene. Av «nye» ting som kommer opp, kan nevnes at det diskuteres litt rundt bruk av kalprotektin for å følge dem med vedvarende lavgradig infeksjon, man stiller spørsmål ved om man trenger å kontrollkoloskopere alle pasienter seks uker etter akutt divertikulitt for å utelukke kreft og ved om det er nødvendig med antibiotikabehandling for ukompliserte akutte divertikulitter, men man nevner så vidt, med kun én setning, muligheten for å gjøre laparoskopisk lavage for dem med Hincheys grad III-sykdom.

Om dette er en «bok» jeg vil anbefale? Nei, jeg tror egentlig ikke det. Når det er sagt, synes jeg konseptet Digestive Diseases har, med temahefter om ulike emner, er bra. Jeg ser ikke bort fra at jeg kunne kommet med motsatt konklusjon om det gjaldt et annet hefte.

\section{Bjørn S. Nedrebø}

Gastrokirurgisk avdeling

Stavanger universitetssjukehus 